\title{
Questionable Embodiment: The Castrato in Corbiau's Farinelli
}

\author{
Grace Kehler
}

\section{Personnification discutable: \\ le castrat dans le film Farinelli de Corbiau}

Le film de 1995 de Corbiau relatant la vie de Farinelli, un castrat célèbre de la fin du dix-huitième siècle, offre à l'audience du vingtième siècle le corps sacrifiéd'un garçon. Kehler se questionne sur ce qui nous attire vers ce corps mutilé du castrat. Sommes-nous, comme l'audience du dixhuitième siècle, attirées par le castrat à cause de notre recherche de la voix d'opéra idéale? Comment l'opéra (en tant quespectacle et en tant que voix) rejoint des questions courantes sur l' identité sexuelle? Kehler argumente que la réintroduction fictive du castrat est reliée à notre obsession contemporaine de la personnification: l'irrésolution du castrat reflète notre fascination pour l'ambiguité de l'identité sexuelle. À travers une lecture historique du film et de l'opéra, Kehler démontre comment la relation entre le corps de Farinelli et sa voix complique, au lieu de les résoudre, les contradictions troublantes de l'identité sexuelle. Le fil épistémologique de l'intrigue du film est constamment menacé par la pluralité et la fragmentation. Une pluralité que le film et la figure du castrat endossent finalement.

White horses galloping in the reveries of a castrato, who attributes his misfortune to these phantoms created by his brother.

A white opium drink to obliterate both false memories and rational objections.

The "white" voices of boy sopranos and castrati, connecting childish piping with adult guilt, and partially undeveloped vocal chords with a grown, masculine body.

A shared red robe, ostensibly signalling the sexual and musical pact of the Broschi brothers, but more sinisterly concealing the elder brother's betrayal.

A bath reddening with a boy's blood. 
These concatenated visual and aural images form the nucleus of Gérard Corbiau's Farinelli, a 1994 film that plumbs the historical, cultural, and physiological enigma of the castrato. If the seductiveness of this figure owed much to its challenge of eighteenth-century limits of definition, the film resuscitates legend and centuries old discourses of gender ambiguity with mutating images and colour symbolism that threaten to overwhelm the spectator with interpretive possibility. White and red, voice and body, private and public, will not stay separate, will not even blend fully to cohere into a distinct unit. Boundaries blur and symbols undergo transvaluation, a challenging state of affairs made more difficult by my conviction that this fluidity is a guilty, cultural indulgence not available to the castrated men who were acted upon and then judged. From the well-fed, richly-clad aristocrats of the seventeenth century to the nostalgic musicologists of the nineteenth century, the assessors of the castrato have spoken his body and voice in terms of entertainment, or art, or morality, in terms of the speakers's multiple desires: angelic voices, monstrous bodies, safe lovers, a third sex, unhuman creatures, social victims, manipulative superstars. These are some of the more persistent representations, but the list is far from exhaustive. My own yearning is informed by a willed naivety, for I am suffused with a desire for an ideal - a transcendent - operatic voice, though I am shocked by my willingness to accede to old claims that base treachery, deliberate mutilation, and a sacrificed, sweet-voiced boy potentially comprise musical perfection and plenitude. Paradox and multiple forms of transgression enhance the lure of the castrato and simultaneously exacerbate my guilt, a conflicted state of affairs that is historically and aesthetically clichéd. Violation sickens me, but were there a castrato to hear, I would afford a ticket.

In spite of Farinelli's modest success at the box office, the appearance of this film assures me that I am not alone in my unreasonable nostalgia. Additional support comes from the now available compact disc of Alessandro Moreschi - the last Sistine chapel and the only recorded castrato; from novels such as Anne Rice's Cry to Heaven (1982), Ross King's Domino (1995) and John Spencer Hill's The Last Castrato (1995); as well as from a highly successful, academic text, Roland Barthes's S/Z (1970). Moreschi's voice, at odds with current vocal ideals and listening practices, satisfies less than "Farinelli's," since, though it is partially constructed out of the embodied voices of Ewa Mallas-Godlewska and 
Derek Lee Ragin, the product is pure myth. The lax throat of the actor Stefano Dionisi-convinces us that "Farinelli" does not really sing, while the sound track envelops us with the seductive sound of the untraceable and unnaturally produced voice - the eerily unreal voice which can appear to coincide with fantasies of perfection. Novels, too, cater to fantasy. Reading these imaginings, I linger on the doubly fictional passages describing the unheard voice (Keats's sweeter songs?). Then, inevitably, I ponder the contemporary relevance of this reconstructed Orpheus, probing his social anomie for more than the pleasure of transgression, more than an ignoble delight in a rarity carved out of human flesh and suffering. Whether I find or generate it, I end with a reading which implicates me afresh in self-referential interpretation, while endeavouring to establish the probity of myself and my contemporaries. I attempt to humanize the legend, to make our reawakened interest in his questionable embodiment symptomatic of twentieth-century perplexity about the body and its relationship to personal identity. How does the body mean? What is its relation to power? To what extent is a body private? Public? Is it discursively produced?

\section{Bodiès Bemuse}

The word-washed body of the castrato provides a remarkably fecund site of exploration for us in the late-twentieth century, given our vertiginous obsession with the physical. The body and sexuality have increasingly gained importance as key to personal identity, for, as Peter Brooks has cogently argued, the body as "the agent and object of desire" is inextricably linked with the desire to know: if narrative is "motivated by an attempted recuperation of otherness, often that otherness is our own body" $(2,5)$. Our sense of embodiment, its physiological, cultural, iconographic, and discursive manifestations, is multivalent, sometimes overwhelmingly prolific, but the resulting challenges to individuals have not stymied our attempts to construct a stable identity and to arrive at a specific reading of the body. In part, then, the fictional reintroduction of the castrato as a figure to be scrutinized and represented is not accidental, but ideological, since his dilemma of undecidability no longer bespeaks only his anatomical freakishness, but also his ability to represent the complexity of identity experienced by many twentieth-century individuals. The represented castrato, whose surgically altered 
anatomy necessarily problematizes his sexual identity and gender relations, endeavours to make a distinction between socially imposed and internally persuasive constructions of desire. Both subject and object, the castrato struggles to take charge of his identity by working through an interpretation of his body.

Corbiau's Farinelli, with its teleological plot, participates in this epistemological decoding (or is it encoding?) of the body as its eponym progresses from object - what Michel Poizat provocatively has designated "the image of what becomes of a subject when it is reduced to its purely enunciative dimension"(127) - to agent; from visual and aural spectacle to a dignified, self-directed musician; and from ironic and/or anguished detachment to social integration. Intriguingly, the project (particularly in its trajectory) reveals its humanistic desire for a recuperative core self, while highlighting the role of competing, external powers and discourses in the production of the body. Confronting these complexities from the start, the film begins with a series of flashbacks, representing the title character's anguished endeavours to reconstruct the relevant incidents leading to his castration: the recollections of Farinelli, born Carlo Broschi, include a naked, suicidal castrato's warning not to sing, and his resulting endeavour to resist being made a vehicle for his elder brother's music in Porpora's music studio. The shots, from a high camera angle, emphasize young Carlo's smallness and vulnerability to Porpora, his brother Riccardo, and his father, who admonishes Carlo never to refuse performance of Riccardo's compositions. Surfeit with connotations, one dilemma uncovered by this scene is that Farinelli, the successful castrato, cannot, even in memories, recall a time when he was not discursively produced by and for others. Prior to castration, the child with the sublime voice, like the adult, is claimed already by family, state, and culture as a vehicle for their musical aspirations; thus the apparently ludic, initial reveries of Farinelli, as they flit from perplexing images of stampeding white horses to his recollection of being singled out for his remarkable instrument, acquire coherence later in the movie, first when Riccardo narrates the story of Carlo's castration after the boy's disastrous fall from a horse and, more significantly, when Farinelli belatedly, unwillingly, uncovers the narrative's mendacity. Riccardo's creation of a castrato was not a result of exigency but desire. The opening sequence, then, though based in part on Riccardo's false information, anticipates Farinelli's realization that he was "marked" before castration, fated by desires and dreams not his 
own. The embodied boy's voice, prepubescent, white, pure, and coveted, makes his body the site of bloody mutilation to forestall permanently certain aspects of sexual and vocal development.

Disturbingly, the flashback also implies that there might be collusion between the body's appropriation by others and one's own bodily generated talent. Imposed desires, after all, might create bodily image, eunuchs, legends, or musicality, but desire alone is impotent when it comes to the singing voice, which cannot be created solely by will or training. Extra-ordinary voices (even the language we use to describe them signals our wonder) inexplicably appear: these voices are ordinary in that they are tied to specific bodies, lungs, diaphragm, vocal chords, chest cavities, and they are "extra," gift, magic, breath, spirit - they are (persistently figured as) the noumenally marked phenomenal and the phenomenally marked noumenal. The voice is of the individual, yet seemingly in excess of his physiological and social make up. Within the movie, this paradox generates internal conflict for Carlo-Farinelli, who appears to himself to be fated for a musical career, but who remains thwarted in his attempts to factor his own desire into his singing.

Further exacerbating the conflict and paradox are the castrato's operatic roles of hero, lover and deity, which render opera's man with a difference the avatar of the mythic and the legendary. As played out in Farinelli, the singer is isolated on the stage, to which he makes grand entrances via horse, a descending chariot from the clouds, or against a lavish, machine driven set, and this grandiosity is rivalled by his towering headdresses. Note: Farinelli's isolation is underscored by his utter singularity within the film as its only represented singer, a fact which we may want to dismiss as cost efficiency, but which has considerably more shattering implications. On stage, he embodies and gives voice to heroic ideals, which nonetheless have a fraught relationship with human agency. In Farinelli's poignant words, after his marriage proposal to Margaret excites immediate, incredulous laughter, "Probably because I often play God on stage, I dared to think I could be a man." The deification of the voice and operatic roles for the castrato constitute a transgressive ideal that does not translate readily or consistently into life, into everyday and off stage embodiment, and therefore functions as a type of social ruse that, after luring the singer into misrecognition, leaves him with a sense of his unknowability. Symbolically, Farinelli's aloneness on the stage, the one place where, historically, the castrato would have interacted with other castrati and with prima donne, signals this 
unknowability. In other words, this particular manifestation of isolation reflects not strictly social or operatic dictates, but the castrato's one psychological surety: he stands single because unintelligible even to himself. Neither legend nor memories of Carlo (the boy who could have become an ordinary man) satisfactorily define his public, performative, and private self.

In another sense, however, one particular legend - that of Orpheus tacitly and explicitly informs Farinelli's self-construction, particularly as mediated by Riccardo. The myth, adapted and rewritten for more than thirty operas, has obvious relevance for the age of the castrato, in which a musician once again is deemed divinely talented and capable of shaping destiny with vocal production. Within the film, this perspective is assigned to Riccardo, who reveals the noxious aspects of such idealism and of attempted mythic reenactment in his attempts to place himself in the double role of creator as composer and of creator of Farinelli/ Orpheus, the legendary singer and lover. As Riccardo envisions his Orpheus, he is to be not the bereaved husband of legend, whose typical, human suffering empowers his most mythic of songs, the lament that restores Eurydice to life; instead, Riccardo desires a profligate lover and a singer who is the apogee and symbol of music, legend divested of its human weakness. Insofar as Farinelli is received as a wonder of song and sexual prowess (the latter a definite departure from history), Riccardo succeeds in scripting his brother's life. But such hypostatized constructions have no personal meaning for Farinelli, who in private agonizes over their hollowness, and no public credibility for Riccardo, the "creator" who habitually discusses Farinelli's talents and opportunities in the plural, personal pronoun. As depicted in the film, the long-standing brotherly pact is both musical and sexual, but it is Farinelli who is desired, lionized, and eventually, independent, leaving the castratingcreator with nothing when his creation rejects the "we" and the "our." Riccardo is alone and, as Handel predicted, silenced: "You have been deprived of your instrument. You're like Narcissus without his reflection. Like Orpheus without his lute.... Without him your music no longer exists. Without him you are nothing but silence." The two mythic references are apt in that they highlight Riccardo's costly vanity and forestalled musicianship, yet the references resonate with stinging irony as well. Neither the beauty or the music belong to Riccardo. He entangles himself in a legend of his own making, but a legend of which he is neither original or copy. 
Farinelli, arguably, does become a recognizably Orphic figure known for his virtually unearthly voice and vocal feats. But the film complicates this construction as well: Corbiau's Farinelli never performs the operatic role of Orpheus as a result of Riccardo's inability to complete his score, begun on the day of Carlo's castration. Alternating between derision and pleading, skepticism and hope, Farinelli longs for Orpheus and strives to steer Riccardo away from his habitual composition of arias of intricate coloratura, which display to advantage the castrato's technical skills and vocal agility. This music, intensifying Farinelli's sense of emptiness, is a correspondingly elaborate display concealing a hollow center. It is structure lacking significant content, surface without depth of emotion. It fails to satisfy Farinelli, the man and the artist, who, following his spectacular London debut, mercilessly parodies the jingle-jangle of his brother's music and subsequently challenges Riccardo in frustration and despair:

"You hear that, Riccardo? After all, you're not deaf. You substitute virtuosity [for] inspiration. All those embellishments and flourishes, all those adornments, that you heap on your scores!"

"I invent them for your voice."

"Forget about my voice!"

"I can't. You know I can't. I promised our father."

"Better think about the music. It should touch the heart. Find the true, essential feeling. I want your music to rouse that fragment of the infinite that lies asleep in their bellies. That's what I ask of you."

"Such ingratitude! What about Orpheus?"

"Orpheus! Orpheus doesn't exist. You'll never finish it."

Farinelli and Riccardo concur that any score based on the tale of Orpheus must communicate profound emotion, but Riccardo cannot afford to probe the emotions or to look beyond the surface of the music or the castrato for whom he composes. That "angelic" voice may still sound pure and white, but it is married to the harrowing emotions of a man who has a vexed relationship with his career, his voice, and his body, all of which have been determined by Riccardo. His guilty creation of Farinelli blocks Riccardo's ability to compose for his brother this poignant tale of loss of love, in which the hero is left only with his plaintive music, the music and emotions merging into a poignant cry to heaven, earth, and even Hades for the gods to restore what has been taken from him. These desolate cries of loss and pain Riccardo attempts to subdue, along with his guilt, by composing scores in which voice and execution work 
against sense and emotion. If Riccardo alone represents Orpheus without his lyre, Farinelli with his brother functions as mere instrument, a played upon producer of noises, which might sound supernatural or unnatural, but never fully human, never fully Orphic. Recurring images of his alienation from his own body and voice - which are prevented from natural development and appropriated for cultural use - threaten the epistemological drive of the plot and its main character with fragmentation, with pluralization into incommensurate parts. How can a figure at once empty and over-determined be recuperated?

\section{May Sorrow Break These Bonds of Torment}

What the film ultimately suggests about ambiguity and contradiction is that they are not simply discursive tools in the hands of the powerful, but also constructs which can be manipulated by the intended objects of discourse. Farinelli's decisive shift from object to agent, from spoken to speaking Orpheus, coincides with his performance of Handel's Rinaldo. Signalling his independence from Riccardo and from public taste for arias replete with embellishments devoid of emotion, Farinelli chooses music which announces his unambiguous assumption of artistic responsibility for what and how he sings, an artistic decision which alters the entire semantics of performance. Working with Riccardo, Farinelli serves as superstar and spectacle, a gelding whose voice and mutilation astonish and titillate audiences. Alternatively, when singing Handel's opera, Farinelli - sans headdress, sans chariot or horse - stands on the stage in simple dress to sing and sing of pain. No longer playing "God" or legend on stage, but instead the suffering individual, Farinelli brings his own emotions into Handel's arias of loss; bereft as performer and as private individual, he is genuinely Orphic in his vocalization of his terrible alienation after being preyed upon by beings more powerful than himself. Both of the Handel arias - "Cara sposa" and "Lascia ch'io pianga" - address the sorrow attendant on being wrenched from a beloved (or, more generally, on the apparent loss of love), and on being imprisoned within a sorcerer's enchanted gardens. In reference to Farinelli, the speciously attractive garden is the stage, which requires his castration and thus separates him from his yearned for beloved, a child of his own; for, as he confides in his young friend Benedict, childlessness constitutes the greatest sorrow of his life. Meaningfully, then, the white dove released by Farinelli in his singing of "Cara sposa," dear spouse, 
flies not to Alexandra, but to Benedict, who first approaches the singer as human and as a potential father figure: "Marry my mother. Let us choose each other. You'll be my father, I'll really be your son." Margaret does not share the desires of her son, and the beloved escapes Farinelli once again, a loss emphasized by his identification of himself with the mechanical birds on stage during his performance of "Cara sposa." Moving his arms in imitation of the machine driven wings of the artificial birds, Farinelli becomes one with the despairing Rinaldo and with the unhuman stage props, a position to which he is reduced persistently by the audience members who consider him an object of mockery or of lust that anticipates penalty free pleasure: he cannot impregnate women. But precisely this transgressive staging of the marriage of surface and depth, of unhuman and human, subverts stereotypes about the castrato and manifests his refusal to stay in the enchanted garden as defined by cultural and operatic authorities. The stage garden transforms into the place where he performs his humanity.

The anarchistic implications arising from the coincidence of performed and private emotion elude audience members at large, but Handel and Riccardo recognize and are "castrated" by Farinelli's staged suffering. Riccardo, lying prostrate and impotent on the rafters above the stage, loses control of his carefully scripted legend, whereas Handel loses his justification for his assumed artistic superiority over Farinelli. From their first meeting, Handel scorns Farinelli as a singer of trifles and, more denigratingly, as a "monster" incapable of stirring the emotions of a "man" who is also a consummate musician. Hence, when this castrato makes Handel's music one with his own artistry and his private emotion, Handel feels that his imagination has been castrated, has been married or even subordinated to all that he regards as less than human. Like Riccardo, who attempts to recastrate the independent Farinelli by dubbing him a creation, Handel attempts to render Farinelli impotent by revealing Riccardo as the castrator, a revelation that makes an utter mockery of the brotherly pact. Yet out of this moment of violation, in which Handel attempts to take from Farinelli his recently acquired sense of artistic integrity, comes the castrato's performance of "Lascia ch'io pianga," another Orphic aria in which power derives not from cultural authority, but from articulations of grief, suffering, longing - articulations of human weakness.

Handel's arias, which are taken out of their historical and operatic context within the film, constitute the symbolic center of the film. "Lascia 
ch'io pianga" in particular comprises the metamorphosis of symbols that appear static and unalterable. Most prominently, the castrato himself seems powerless to decide his own fate, since, if he does not consent to be a musical toy for the public, he will be the eunuch who lacks a voice and lacks as well, as Handel sneers, a reason for his existence. Typically, Farinelli hides from his own powerlessness by treating those around him with elaborate irony and cool appraisal, attempting in turn to wound them with his indifference. Singing "Lascia ch'io pianga," though, he dons powerlessness as he dons a red robe, the sign of his physiological impotence that led to his sexual pact with Riccardo: Farinelli attracts the women and gives them pleasure, and, subsequently, the singer takes the red robe from Riccardo, who attempts to impregnate them. Transferred onto the stage and into an opera in which Riccardo has no share, the red robe designates Farinelli's breaking of the pact and his acknowledgement of his lost virility and his lost sense of fraternity. In this context, the aria underscores the horror of loss and beauty of voice peculiar to the castratro, while still preserving traces of another social role marked by impotence: the feminine. In the original score, the aria belonged to the prima donna. In choosing to shift from the relatively heroic role of Rinaldo, who sings "Cara sposa," to the feminine and feminized role of Almirena, whose music includes "Lascia ch"io pianga" (a historically implausible shift within a single performance of an opera), Farinelli sings a double-voiced suffering. Notably, this vocalization of "Lascia ch'io pianga" redefines painful emotion as generative of (self) knowledge and its accompanying power to refute or modify imposed social constructions. Unfortunately, the vocal poignancy must remain unspoken here, for I can transcribe only the words:

Let me weep

for my black fate

and let me yearn

for liberty.

May sorrow break

these bonds

of torment

alone for pity's sake.

If Farinelli can effect his own release from empty music and selfhood by deploying private emotion to define the public self, he apparently pleads in this aria for freedom from the dispassionate, dehumanized social 
views of the castrato, bonds which might be broken by sorrow. For Alexandra, who chokes back her tears during "Lascia ch'io pianga," Farinelli in anguish and endowed with this terrible gift of sublime music evokes a love for which she sacrifices social position and the convention of marriage. Anguish, in fact, is also what prevents her from despising Riccardo, whose face when he suffers, she says, is "poignantly reminiscent" of his brother's. Emotion pluralizes and radicalizes social hierarchies and human relationships.

The film never trivializes the physical and symbolic violation of Farinelli, even while multiplying the connotations of castration, though the process of pluralization also works to qualify and partially mitigate the castrato's alienation. "Lascia ch'io pianga," for instance, humanizes the castrato and implicates in his pain all of those who imprison him, an implication which is not merely accusatory: it is also an indication of commonality, suggesting that myopia and constraint inhere in the social convention of defining oneself purely in opposition to others. Until Farinelli's performance of the Handel arias, the camera primarily reflects the castrato's psychological perspective of events and people, subtly underscoring this figure's distinction and alienation. By contrast, in the filming of the Handel arias, the camera features Farinelli's pain as a prelude to introducing the suffering of those with whom his life is intertwined emotionally and artistically: Benedict, Alexandra, Riccardo, and Handel. The camera cuts from one sad face to another, and the cuts are interspersed with flashbacks to memories of Carlo's enforced singing for his brother's music and of Carlo's castration, painful memories now implicitly shared by Farinelli and Riccardo. The voice and the body of the castrato, generally associated with a wrenching indeterminacy that places him somewhere between the masculine and the feminine, here serves as a link between masculine and feminine as the castrato vocalizes and dramatizes the sorrow endemic to the either role: Rinaldo or Almirena, or castrator or castrated. (This capacity is underscored by the film's production of a "castrato's" voice, which is an electronicallymixed composite of a soprano and a counter-tenor.) As Roland Barthes so insightfully observes in $S / Z$, "the symbolic field is not that of the biological sexes; it is that of castration: of castrating/castrated, active/passive" (36). Across this field the castrato "moves back and forth between active and passive," a mobility that consequently alters the position of others (36). In Corbiau's film, too, female and male characters occupy unstable positions in the field, doubling as literal and symbolic 
castrators and as impotent, suffering individuals. More provocatively and paradoxically still, in Farinelli power may be generated by embracing weakness. Sorrow may break or ease the bonds of torment.

\section{Cara Sposa Revisited}

If the first mystery of the movie is Riccardo's betrayal of his brother, the second one concerns embodiment and its complex plurality that opens up possibilities even in apparently fated scripts. This capaciousness rescues the plot from becoming simply an exotic version of overworked and often banal scripts such as boy meets girl or misfits in love. The ending of the film initially constituted for me a troublingly reductive solution to a disturbingly complex narrative. Farinelli discontinues his performances, which combine surface and depth, and withdraws into private life as "husband" and expectant "father." The castrato apparently is made whole by the sacrifice of Alexandra's body to the desires of the Broschi brothers: Riccardo trades his finally completed Orpheus score for another "joint creation," while Carlo trades unshared intimacy with Alexandra for a child, the long-awaited beloved. One implication is that manliness and fulfilment derive from illusions of authority, notably that of paternity. Riccardo, assuming the position of authority after the death of the father, takes charge of Carlo's life and body, and the adult Carlo assumes paternity in relationship to Riccardo's child. Alexandra, in tears once again as she allows Riccardo into her bed and body, seems to reprise Farinelli's role as a vehicle for the desires of others.

Still, my admiration for the movie and my impulse to read recuperatively do not allow me to stop with this one reading of violation. I also want to see the multiple triangulated relationships (Carlo-AlexandraRiccardo, Carlo-child-Alexandra, Alexandra-child-Riccardo) as part of the movie's endeavour to demonstrate that identity can have its genesis in relation to, rather than in distinction from, others. Peter Brooks, who takes his cue from Georges Bataille, suggests that the erotic encounter may represent the desire to breach finitude and to open up the body: "Putting one's body at risk in this manner creates a disequilibrium in which one consciously puts oneself into question. The erotic thus offers a momentary transcendence of limits, of discontinuity. It is comparable to sacrifice, as the revelation - and creation - of the sacred" (275). Sacrifice and eroticism enact the belief that the barriers between physical bodies are negotiable, and both create the sacred because the body 
(particularly in death) opens itself up to the desires of others and offers itself for another and for another's benefit. In the sacred rituals of many cultures, sacrifice and gift are one, and Alexandra's sacrifice literally encompasses the gift of life. Though acted upon, her body participates in the creation of new life: hers, Farinelli's, and the child's. The movie ends, then, as it begins, with the mystery and plurality of embodiment. Clearly, the scripts of embodiment contain scenes of violation, which understandably make us riled, uncomfortable, resentful, but the excess of the body, often salutary, continually puts in question our attempts to impose narrative closure.

\section{Works Cited}

Barthes, Roland. S/Z. Trans. Richard Miller. New York: Hill and Wang, 1974.

Brooks, Peter. Body Work: Objects of Desire in Modern Narrative.

Cambridge: Harvard UP, 1993.

Farinelli. Dir. Gérard Corbiau. With Stefano Dionisi. Stephan Films, 1994.

Hill, John Spencer. The Last Castrato. London: Constable, 1995.

King, Ross. Domino. London: Sinclair-Stevenson, 1995.

Poizat, Michel. The Angel's Cry: Beyond the Pleasure Principle in Opera.

Trans. Arthur Denner. Ithaca: Cornell UP, 1992.

Rice, Anne. Cry to Heaven. New York: Ballantine, 1982. 